\title{
Rhammatocerus schistocercoides locust outbreaks in Mato Grosso (Brazil): a long-standing phenomenon
}

\author{
M. Lecoq ${ }^{1}$ and I. Pierozzi Jr ${ }^{2}$ \\ ${ }^{1}$ CIRAD-GERDAT-PRIFAS, Montpellier, France \\ "EMBRAPA-NMA, São Quirino, Campinas SP, Brazil
}

Key words: Acrididae, locust outbreaks, Rhammatocerus, Brazil, tree savanna, deforestation, agriculture

\begin{abstract}
SUMMARY
Evidence obtained orally or from publications clearly indicate that Rhammatocerus schistocercoides Rehn, 1906 (Orthoptera: Acrididae Gomphocerinae) outbreaks in Mato Grosso (Brazil) are a long-standing phenomenon, both in terms of their extent and nature. Current theories on the origins of these outbreaks therefore must be drastically revised, especially those that blame the accelerated agricultural development that has occurred in these regions since 1980.
\end{abstract}

\section{INTRODUCTION}

In the Mato Grosso state and, to a lesser extent, in the Rondônia state in Brazil, there have been serious outbreaks of Rhammatocerus schistocercoides Rehn, 1906 (Orthoptera: Acrididae, Gomphocerinae), a locust species that previously was considered harmless (Cosenza et al., 1990). The affected areas are mainly in a strip of cerrados (tree savannas), just south of the Amazon forest, extending from the border of Rondônia state in the west to the Rio Araguaia valley in the east, in the Chapada dos Parecis region sensu lato (Figure 1). Substantial locust control treatments have been carried out in certain years since then, and these have had considerable economic and environmental impacts.

The locust species involved in these outbreaks was only confirmed after several misidentifications (Carbonell, 1988), and its ecology has not yet been thoroughly investigated (Lecoq and Pierozzi
Jr, 1993, 1994; Miranda et al., 1994). Both the hoppers and adults can be highly gregarious, characterized by banding and swarming behaviour. There is one yearly reproduction cycle. The hoppers develop slowly during the rainy season, while the imagos are present in the dry season and breed at the beginning of the following rainy season.

The factors that determine outbreaks are still unclear. Many highly controversial hypotheses have been proposed, the main one being that it is the accelerated agricultural development that began in the 1980s in the concerned areas that is at least partially responsible for the locust problem. According to this hypothesis, the intensive deforestation carried out to create croplands and pasturelands would have created new biotopes suitable for locusts, or an upset in the ecological balance would have considerably reduced natural locust predators and promoted outbreaks (Lecoq and Pierozzi Jr, 1993;

Correspondence: Dr Michel Lecog, CIRAD-GERDAT-PRIFAS, B.P. 5035, 34032 Montpellier Cedex 1, France 


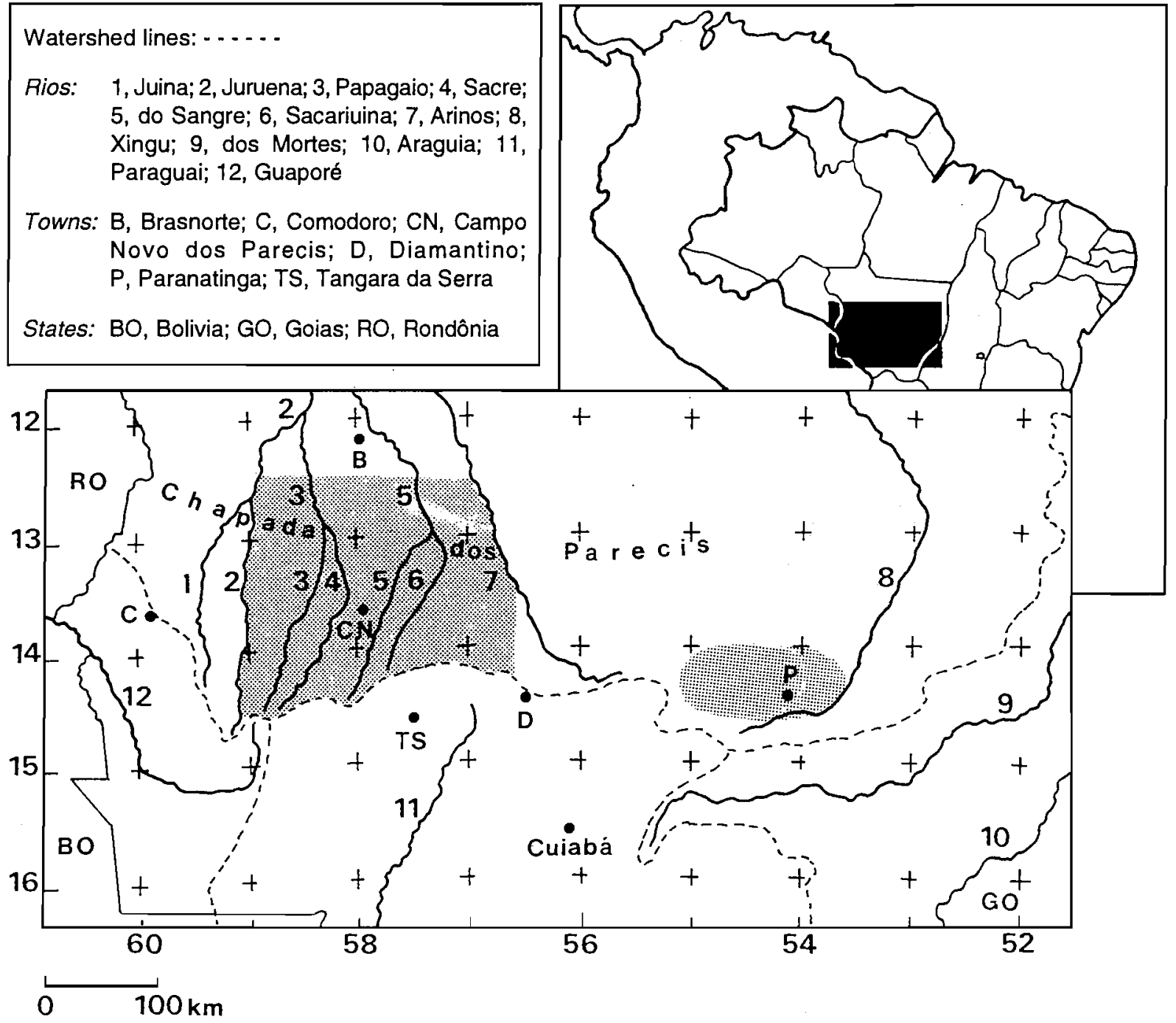

Figure 1 Approximate boundaries of the main zones of Rhammatocerus schistocercoides outbreaks (shaded, on main map) reported since the beginning of the century

Barrientos, 1993). Although these hypotheses have not been confirmed scientifically to date, they have been put forward regularly (particularly by the media) and thus have insidiously become accepted as being true.

As part of a research project aimed at laying the scientific foundations for a strategy for control of this species, we have considered the problem in a general ecological context and investigated whether outbreaks of this species are a longstanding or recent phenomenon. Evidence obtained orally and from publications clearly indicated that, although the economic problem created by outbreaks of this locust in Mato Grosso is recent, it is a long-standing phenomenon. Hence, current theories on the origins of the outbreaks must be drastically revised and many previous hypotheses should be rejected.

\section{METHODS}

An extensive bibliographical search of all available documents concerning ethnology and exploration in Mato Grosso was carried out. In addition, field missions were conducted to contact local old people who could provide some background on the situation in areas where the locust outbreaks have occurred (particularly Chapada dos Parecis). Thus, Indians, old farmers, pioneers who had colonized Mato Grosso, anthropologists, Jesuit and Salesian missionaries, herdsmen, seringueiros (rubber collectors), etc. were approached. 
In general, the people questioned were able to identify $R$. schistocercoides easily. Renowned for causing serious outbreaks, it is a typical species in the region and cannot be confused with any other type of locusts. Most of the people questioned recognized it immediately and were able to distinguish between $R$. schistocercoides and Tropidacrisspp. The latter species are spectacularly large (in comparison) and are well-known locusts in the area; they are also gregarious in the hopper stage.

Identifications reported in the literature must be considered with caution. Locust outbreaks in Mato Grosso have often been reported as being due to Schistocerca cancellata (Serville, 1838) (Setz, 1983,1991 ), or a synonymous species $S$. paranensis (Burmeister, 1861) (Correa, 1969). In fact, most reported identifications prior to Carbonell's recharacterization of the species in 1988 were erroneous. It is now certain that probably all locust swarms observed on the Chapada dos Parecis concerned $R$. schistocercoides. For instance, we assessed the specimens (preserved in alcohol) and photographs collected by Setz $(1983,1991)$ and found that they belonged to the genus Rhammatocerus, not Schistocerca as reported.

\section{RESULTS}

\section{Data on the long-standing status of locust outbreaks}

Anthropological data on the diets of various Indian tribes, particularly the Nambiquaras and Baikiri, provided the first evidence on the importance of locusts in the Chapada dos Parecis region. They indicate that locusts have long been a key component of the local ecosystem.

As early as the 1930s, Claude Levi-Strauss reported that locusts were eaten by the Nambiquaras (Levi-Strauss, 1948, 1979). Eléonore Setz, in a study carried out in the 1970s, also noted that locusts are an essential part of the daily diet of these Indians. Bands of $R$. schistocercoides hoppers (in the rainy season) and imagos (in the dry season) are hunted by the Indians. They use branches and flaming torches to surround the hopper bands and channel them towards trenches. The hoppers are then caught and put in to large baskets that are quickly filled. Adults are captured by hand in the morning when they are inactive, because of the cool temperatures, and thus easier to catch. The locusts are then toasted over charcoal and eaten as such, mixed with fruit juices, or added to cassava flour to make a type of bread. They are consumed daily by the Indians in some form (Setz, 1983, 1991). There are also numerous reports that Baikiri Indians in the Paranatinga region consume locusts.

Myths of the Parecis Indians also highlight the importance of locusts on the Chapada, with several locust species having prime roles (Pereira, 1986). In a Parecis myth about the creation of the world, the locust arises from a leg of a mythical Indian hero called Miore. A locust also plays the role of Promethius by inadvertently burning the bush, providing man with fire. In Parecis mythology, there is thus a very close and long-standing relationship between Indians and locusts. Reference to this conviviality since the creation of the world is strong evidence that large locust populations have been present on the Chapada since ancient times. In addition, the link between fire and locusts highlights the important role of burning in locust population dynamics. This practice favours grass regrowth during the dry season, which in turn provides food to enable adult locusts to survive through this season; they can then breed after the first rains. The Indians have obviously long been aware of this relationship, because bush burning is a very common Indian practice. This trend can be observed on satellite maps of vegetation which show evidence of a highly marked burning effect on the plant cover in Indian reservations, revealing that it is extensive and recurs frequently over time.

In more concrete terms, from 1907 to 1912 Marshal Rondon provided the first reliable accounts of locust outbreaks in Mato Grosso in various reports and conferences concerning his trips to Chapada dos Parecis during the construction of the Cuiabá-Amazon telegraph line (Anon., 1914, 1915; Rondon, 1919; Viveiros, 1969).

Rondon (1919) stated that this region is a 'locust paradise' ('Eden dos gafanhotos') where the insects upsurge and form considerable swarms in the area extending east to west between the upper courses of the Rios Arinos and Juruena, for about $2^{\circ}$ northward from the watershed between the Rios Paraguay and Tapajós basins. Upon 
entering the Parecis territory, in September 1907, he noted the presence of an enormous quantity of locusts:

Before arriving at the Rio Xacuruina, a tributary of the Rio Sacuriu-iná, I passed by the source of the Rio Tres Jacus, where a group of rubber collectors was camped. I then crossed a broad plateau and there, for the first time, I observed terrifying swarms of locusts that destroyed everything in their way.

... In all areas, extraordinary swarms of small locusts made walking difficult for our animals. At our camp on the Rio Burity, my tent was invaded by these starving insects which damaged all of my clothing in little time. I think that they are the same locusts that migrate to the Argentine pampas, since we observed a southward migration of these pest insects, in such quantities that the sky was darkened [the real origins of these locusts are discussed later].

Roquette-Pinto (1935) confirmed these locust outbreaks at the beginning of the century. Concerning a trip to Chapada dos Parecis in 1912, he noted that 'locusts covered the sky and made walking difficult when we crossed zones in the Chapada with sandy soils'.

Also at the outset of the century, during his trips to Mato Grosso from 1908 to 1914, Hoechne (1951) found that farming was impossible on the Chapada dos Parecis because of the type of soils and constant locust outbreaks occurring in the zone. He also pointed out that 'to avoid disastrous cataclysms, everything must be done to stop destruction of the forests that flourish along the edges and at the foot of the Chapada dos Parecis, as long as eradication of locust outbreak centres has not been successful'. For Hoechne, these forest edges represented an effective blockade against swarm movements.

Concerning the same locust outbreaks at the beginning of the century, Edie Pina de Barros, Head of the Anthropology Department at the Federal University of Mato Grosso, told us that her living grandmother, born in 1892 of Baikiri origin, was able to clearly identify the locusts as $R$ schistocercoides. She confirmed that substantial outbreaks of this species occurred during her youth (at the end of the last century and beginning of the twentieth century) on Baikiri land in what is now known as the Paranatinga region.

According to the traditional oral accounts of the Baikiri Indians, important locusts outbreaks have taken place since the end of the nineteenth century. These reports can be dated approximately by comparison with the dates of important events or famous visits. Hence, in the current Baikiri reservation, there were marked locust outbreaks at the end of the nineteenth/ beginning of the twentieth century, and also in the 1940s (pers. comm., Edie Pina de Barros, 1993).

There is much evidence which indicates that there have been constant locust outbreaks on the Chapada during the present century. The Jesuit priest José de Moura e Silva, current Director of Public Archives in Mato Grosso, has visited the Chapada dos Parecis region regularly since 1953. He confirms that, every year, swarms of a species which could only be $R$ schistocercoides are regularly present, especially in the Utiariti region where his visits have mainly been focused. He has observed some inter-annual variability in locust populations, but considers that locusts are always present in high numbers.

In his book on the history of Mato Grosso, Virgilio Correa Filho (1969) mentions that locust outbreaks occur on the Chapada dos Parecis:

Locusts - considered as a treat by the Nambiquaras - have established their operational base in sandy areas of the Parecis. From there, they migrate southwards in dense formations at certain times of the year, searching for crops to satisfy their ferocious appetites.

His military metaphor reflects the importance of the reported phenomenon.

Antonio Amorin, 66 years old and now living in Cuiabá, was a herdsman and seringueiro at the time of the 'rubber soldiers'. He passed through the Chapada dos Parecis often from 1944 to 1967. He was able to identify the locusts perfectly and remembers very well that, as early as 1944 in the Agua Limpa region and near the source of the Rio do Sangre, many swarms took flight when his herds passed. The grass was completely eaten by the locusts, leaving bare ground. He claimed that he observed such swarms every year in the dry season from 1944; densities varied but there were always many locusts. He was also able to describe precisely their swarm flight behaviour: flying $20 \mathrm{~m}$ above ground at the most, they are carried by the wind for short distances (no more than a few hundred metres) and they land and take off again. He confirmed that the Nambiquaras Indians eat 
locusts that they catch in bags; they cut their wings, fill their baskets, and toast or grind them into flour which is used to season meats. $\mathrm{He}$ pointed out that locusts were found throughout the campo cerrado zones on sandy soils, and that their densities were always higher from the Rio do Sangre to Diamantino, with fewer locusts present between the Rio do Sangre and Juruena. He also observed large swarms in Guaporé valley, in western Mato Grosso, in campo regions with sandy soils in the middle of the forest. Finally, he noted high locust densities in the driest years, and low densities in the wettest years.

Bernard Radoux, head of FUNAI (National Indian Foundation) at Utiariti, and João Garimpeiro, cacique (Indian chief) of the Parecis, confirmed that the Indians have always known locusts, whose population densities vary yearly, and that there have always been outbreaks.

Concerning the western Mato Grosso, further evidence on the history of locust outbreaks on the Chapada dos Parecis was obtained in a report by Sick (1965) on cerrado fauna. The author stated that, on the Chapada at some times of the year, campo cerrado regions are 'teeming' with locusts, especially herbivores - a clear reference to $R$ schistocercoides. This author also reported observing Tropidacris sp.

Evidence that locust outbreaks are a longstanding phenomenon is not limited to the western Mato Grosso and regions around the Parecis and Nambiquaras Indian reserves, which are considered to be the source of the outbreaks that have occurred since 1984. Several accounts indicate that important outbreaks have already occurred further east, particularly in the Paranatinga region. In addition to the accounts of Edie Pina de Barros discussed above, many old farmers from the Paranatinga region have provided some baseline information on the former situation.

One of the most interesting accounts was obtained from Bernardino Gomes Bezerra, who has been farming in the Paranatinga region for over 60 years (since 1932), and his family has lived in the region since 1928 . He was easily able to identify mounted $R$. schistocercoides specimens. This farmer claimed that locust outbreaks are not a new phenomenon in the Paranatinga region and recalled observing very serious outbreaks at the end of the 1940s, especially in 1947. Between
May and November of this particular year, he said there were swarms everywhere for about $60 \mathrm{~km}$, from his father's fazenda (Fazenda Rancharia, now in Nova Brasilândia county), located on the edge of the Baikiri Indian reserve, to the site of the future town of Paranatinga. These low-flying locust swarms were up to $2 \mathrm{~km}$ long, and made walking difficult. Mr Bezerra also gave a good description of typical swarm behaviour. These outbreaks lasted for 5-6 years, until about 1952, and then they stopped. According to this farmer, there were many more locusts in the 1947-1952 period than over the past 10 years. Moreover, the locust situation seems to have been less of a problem between these two major outbreak periods. He believes that the locusts disappeared because of heavy rains which killed masses of hoppers. He also considered that the drought that had occurred for some years during this period was detrimental to the locusts. This account was in agreement with that cited earlier concerning the presence of outbreaks in the Paranatinga region in the 1940s. These outbreaks were also confirmed by other witnesses. Marcelino Sampaio, who has lived in the region for about 60 years, and is now employed at the 'Lojas das Américas' store in Paranatinga, claimed that he observed locust outbreaks in the years around 1948-1950 at Rancharia, where he had a small property.

More recently, Gentil Mariano Miotto, a farmer at Paranatinga and originally from Rio Grande do Sul, pointed out that there were locust swarms present as soon as he arrived in the region in 1983, particularly around the site called Sete Placas, and near the Rondon Indian reserve. This was before the first official reports of locust outbreaks in this zone in 1985.

All of these different accounts confirm that locusts have also been a long-standing problem in the Paranatinga region. Some of the people questioned even believed that the past outbreaks were worse than those that have occurred more recently. Indeed, locust swarms were noted in the region before 1985 (as early as 1983) and possibly greater outbreaks occurred earlier, notably between 1947 and 1952 and at the beginning of the century. These outbreaks, however, do not seem to have occurred as frequently as in the Chapada dos Parecis region, where the phenomenon seems to have been constant. 


\section{DISCUSSION AND CONCLUSION}

The variety of evidence obtained either orally or from publications clearly indicate four main conclusions. Firstly, it demonstrates that the locust outbreaks are a very long-standing phenomenon in Mato Grosso. Secondly, the extent and frequency of past and present outbreaks are identical. All evidence highlights the importance of outbreaks since the beginning of the century. Some even consider that such outbreaks are a factor that could prevent the development of agriculture on the Chapada dos Parecis, thus indicating their seriousness.

A third indication is that these outbreaks have always (or at least since the end of the nineteenth century) affected a large strip of land stretching from the area of the Guaporé Rio valley westward to the Paranatinga region eastward, and schematically from $12^{\circ}$ to $15^{\circ}$ latitude $S$. The two main outbreak areas have not changed over the century: the Chapada dos Parecis and the Paranatinga region. However, outbreaks seem to be less frequent in the Paranatinga region, whereas they are almost continuous in the west, on the Chapada dos Parecis itself, although their extent varies yearly.

A fourth main conclusion is that the species involved in the outbreaks could only have been $R$. schistocercoides. Each separate account certainly cannot be taken as a proof of identification. However, apart from specimen identifications by some witnesses, the overall evidence indicates that locust outbreaks have occurred for a very long time in Mato Grosso. The ecology and behaviour of the species described match those of $R$. schistocercoides. Moreover, the outbreak areas have not changed since the beginning of the century, and are habitats in which $R$. schistocercoides are now found - i.e. campo-cerrado zones with sandy soils. Some early reports attributed the outbreaks to Schistocerca cancellata (Serville, 1838), a migratory locust whose outbreak areas are located in northern Argentina, but this was because $R$. schistocercoides was not at the time a scientifically characterized species (apart from a brief description by Rehn in 1906 that was soon ignored). It was long considered that $S$. cancellata was the only gregarious locust in South America with swarming behaviour, and therefore all outbreaks until recently were attributed to this species. This was also the case in the Nordeste region of Brazil, where outbreaks of $S$. pallens were taken for those of $S$. cancellata. The authors obtained first-hand evidence of such identification errors in a collection of $R$. schistocercoides hoppers that E. Setz had mistakenly identified as Schistocerca sp. Finally, Hoechne's (1951) comments on the importance of forest zones around the periphery of the Chapada dos Parecis (for the purpose of hindering locust movements) indicate clearly that this author was referring to a local species of locust.

This evidence for long-standing locust outbreaks in Mato Grosso confirms the reports from several observers, since the beginning of the recent 'official' outbreaks in 1984.

In 1986, at the 5th Meeting of Amazonian Scientists at Manaus (Brazil), Maria Fátima Roberto Machado stressed the fact that locust outbreaks are not simply a recent occurrence in Mato Grosso. This was based on the accounts of Marshal Rondon (Machado, 1986). In addition, Jacob Ronaldo Kuffner (1988), a locust control co-ordinator, pointed out in his report that the outbreaks are probably a long-standing phenomenon. He based his comments on Marshal Rondon's reports, and on accounts from people who had lived for a long time on the Chapada dos Parecis, and from the oldest indigenous people, thus confirming the presence of very large locust populations for several decades in the region. The same author claimed that past outbreaks were considered merely as a curiosity in this region because there was almost no farming, and herding was conducted on a low-intensity scale, limited to natural cerrado zones.

In recent years, therefore, there has been a different outlook on the locust outbreaks, contrasting with the commonly held viewpoint that they are a recent phenomenon caused by the intensive agricultural development in the 1980s (i.e. the creation of new biotopes favourable to locusts, or the disturbance to the ecological balance, such that the natural enemies of these pests are reduced in number). Unfortunately, this new outlook has been almost completely ignored.

The fact that there is a long history of $R$. schistocercoides outbreaks on the Chapada is critical to an understanding of the phenomenon and in determining its origins. Hence, all previous 
theories are obsolete, and intensive mechanized agricultural development should not be proposed as an explanation for the phenomenon.

The outbreaks might be long-standing, but the economic problem created by this locust in Mato Grosso is obviously recent. It began in the 1980s, at the beginning of the intensive agricultural development when crops were introduced into the usual $R$ schistocercoides outbreak areas. Swarms start forming in April and have a typical nomadic behaviour during the entire dry season, until the rainy season draws near, when they breed and partially settle. These nomadic swarms naturally encountered the new cultivated areas and caused damage, especially to crops that closely resembled their usual food - i.e. grasses: mainly rice, sugarcane and corn. In the rainy season, hopper bands invaded such crops and also caused damage there.

New farmers, mainly immigrants from southern Brazil, were unfamiliar with the region and its past situation. They were thus surprised to see their first crops threatened or destroyed by an insect that they had never encountered previously, even though it is regarded as a key entomofaunal component of local ecosystems. This gave rise to the 'legend' of a new problem. This legend was welcomed in the current cultural environment, characterized by problems concerning Amazonian deforestation, agricultural conflicts between Indians and the new farmers, and criticism concerning cropping techniques used by these immigrants. This has been a very heated but mainly polemical debate.

It is clear from the evidence reported above that the recent environmental modifications in Mato Grosso (deforestation, the development of the cerrado, increase in croplands and pasturelands, reduction of natural fauna, etc.) have not affected the locust situation. The hypothesis that these modifications have created new favourable biotopes is unfounded. In contrast, our initial field results have revealed that the creation of new agricultural zones on the Chapada has destroyed natural locust biotopes and breeding grounds, without providing favourable substitute areas (except temporarily in a few cases) (Miranda et al., 1994). Some people interviewed even suggested that the locust outbreaks might decline in the near future with the extension of croplands, thus gradually reducing potential locust breeding sites. Moreover, considering the facts presented earlier, it is unlikely that an ecological imbalance in the region concerned (if there is one) has reduced the locusts' natural enemies (not yet proven). This is in agreement with the results from many studies of locust population dynamics that have been carried out worldwide. In general terms, and for most acridian species, it is known that abiotic factors (particularly meteorological) have a prime role in determining outbreaks, whereas biotic factors - despite being highly diverse (e.g. parasitism, diseases, predators, etc.) and often with spectacular temporary impacts - are relatively unimportant (Dempster, 1963; Joern and Gaines, 1990). For example, Farrow (1977, 1982), in a study on the Australian locust Chortoicetes terminifera (Walker, 1870), demonstrated that the effects of natural enemies on locust population dynamics decrease during upsurges and increase again as the outbreaks subside; thus they only precipitate the breakdown of a locust population.

Finally, the fact that outbreaks have long been recorded in the eastern Mato Grosso (in the Paranatinga region) indicates that deforestation is probably not entirely responsible for allowing locust swarms to exit from the western part of the Chapada dos Parecis region and move in to eastern Mato Grosso, as often currently suggested, and as proposed by Roquette-Pinto at the beginning of the century.

Since the present hypotheses on this topic are now obsolete, new research areas should be investigated to understand the determining factors of $R$. schistocercoides outbreak cycles. The hypothesis of a meteorological correlation seems particularly promising. Many of the observers consulted emphasized a likely relationship between rainfall intensity and the extent of outbreaks. Calm years and outbreak years seem, historically, to have long followed one another at a rapid rhythm, and this is probably related to the varying impact of several abiotic factors at very precise stages of the locust's life cycle. Research should now be aimed at obtaining an understanding of these key factors and how they affect population dynamics. It already seems probable that the irregularity of rainfall at certain key periods of the locust's life cycle (sexual maturation, oviposition and embryo development) has an important role which should be defined.

The recent anthropic changes, although not deterministic, should not be ignored, since they 
will increase during the years to come. Beyond present speculations, their impact on locusts, which might be quite different from that set out in common hypotheses, should be the topic of specific analyses. In a future study, we will analyse the impact of anthropic changes on locusts and their population dynamics.

\section{ACKNOWLEDGEMENT}

The present work has been funded by the European Community.

\section{REFERENCES}

Anon. (1914). Uma expedição ao Rio Juruena (De algumas Conferencias do illustrado mattogrossense Tente. Corl Dr. Cândido Mariano da Silva Rondon, effectuadas no Rio de Janeiro). In Album graphico do estado de Matto-Grosso,

Anon. (1915). Missāo Rondon. Apontamentos sobre os trabalhos realizados pela Comissão de Linhas telegráficas e estratégicas de Mato Grosso ao Amazonas sob a direção do Coronel de Engenharia 'Candido Mariano da Silva Rondon' de 1907 a 1915. Jornal do Comercio (Rio de Janeiro)

Barrientos, L.L. (1993). The present state of the locust and grasshopper problem in Brazil. Metaleptea, 14,11

Carbonell, C.S. (1988). Rhammatocerus schistocercoides (Rehn, 1906), especie perjudicial para la agricultura en la region centro oeste de Brasil (Orthoptera, Acrididae, Gomphocerinae). Boletim do Museo Nacional de Rio de Janeiro, Zoologia, 318, 1-17

Correa Filho V. (1969). História de Mato Grosso. (Rio de Janeiro: Instituto Nacional do Livro)

Cosenza, G.W., Curti, J.B. and Paro, H. (1990). Comportamento e controle do gafanhoto Rhammatocerus schistocercoides (Rehn, 1906) no Mato Grosso. Pesquisa agropecuaria brasileira, Brasilia, 25, $173-80$

Dempster, J.P. (1963). The population dynamics of grasshoppers and locusts. Biological Reviews of the Cambridge Philosophical Society, 38, 490-529

Farrow, R.A. (1977). Origin and decline of the 1973 plague locust outbreak in central western New South Wales. Australian Journal of Zoology, 25, 455-89

Farrow, R.A. (1982). Population dynamics of the Australian Plague Locust, Chortoicetes terminifera (Walker) in central western New South Wales. III. Analysis of population processes. Australian Journal of Zoology, 30, 569-79

Hoechne, F.C. (1951). Mato Grosso, contraste do seu nome. In Relatório Anual do Instituto de Botânica referente ao exercicio de 1949, pp. 45-51. (São Paulo: Instituto de Botânica)
Joern, A. and Gaines, S.B. (1990). Population dynamics and regulation in grasshoppers. In Chapman, R.F. and Joern, A. (eds.) Biology of Grasshoppers, pp. 41582. (New York: John Wiley and Sons)

Kuffner,J.R. (1988). A campanha de combate aogafanhoto. Unpublished document, Delegacia Federal de Agricultura em Mato Grosso, Cuiabá

Lecoq, M. and Pierozzi Jr, I. (1993). Rhammatocerus schistocercoides (Rehn 1906), Criquet Ravageurde l'État du Mato Grosso au Brésil. Essai de Synthèse Bibliographique. (Montpellier, France: CIRAD)

Lecoq, M. and Pierozzi Jr, I. (1994). Les stades larvaires de Rhammatocerus schistocercoides (Rehn 1906) [Orthop. Acrididae Gomphocerinae], criquet ravageur de l'état du Mato Grosso, au Brésil. Bulletin de la Société Entomologique de France, 99, 525-35

Levi-Strauss, C. (1948). La vie familiale et sociale des Indiens Nambikwara. Journal de la Société des Américanistes (NS) , 37, 1-131

Levi-Strauss, C. (1979). Tristes Trópicos. (Lisboa: Ediçōes 70)

Machado, M.F.R. (1986). Relaçōes interetnicas e debate ecológico en Mato Grosso. Unpublished document, Department of Anthropology, Cuiabá MT

Miranda, E.E. de, Pierozzi Jr, I., Batistella, M., Duranton, J.-F. and Lecoq, M. (1994). Static and dynamic cartographies of the biotopes of the grasshopper Rhammatocerus schistocercoides (Rehn, 1906) in the state of Mato Grosso, Brazil. Presented at the International Symposium on Resource and Environmental Monitoring (International Society for Photogrammetry and Remote Sensing), ECO'RIO, Riode Janeiro, Brazil, September 1994

Pereira, A.H. (1986). O pensamento mítico do Paresí. la parte. Pesquisas, Antropologia, 41, 1-441

Rondon, C. M. da S. (1919). Relatório apresentado à Diretoria Geral dos Telégrafos eà Divisão de Engenharia do Departamento da Guerra pelo Tte. Coronel Cândido Mariano da Silva Rondon, Chefe da Commissäo. ( $2^{\circ}$ volume) Construção (1907-1910). Publ. No. 39. (Rio de Janeiro: Pap. Macedo)

Roquette-Pinto, E. (1935). Rondônia, 3rd edn., Vol. 39. (São Paulo: Companhia Editora Nacional) 
Setz, E.Z.F. (1983). Ecologia alimentor em um grupo indigena: comparação de aldeias Nambiquara de Floresta $\varepsilon$ de cerrado. Unpublished MSc. thesis, State University of Campinas, São Paulo

Setz, E. Z.F. (1991). Animals in the Nambiquara diet: methods of collection and processing. Journal of Ethnobiology, 11, 1-22
Sick, H. (1965). Afauna do cerrado. Arquivos de Zoologia (São Paulo), 12, 71-93

Viveiros, E. de (1969). Rondon Conta sua Vida. (Rio de Janeiro: Cooperativa Cultural dos Esperantistas) 